\title{
The ophthalmologic signs in case of C1 neurinoma without hydrocephalus - case report
}

\section{Zaburzenia oftalmologiczne u chorego z guzem połączenia czaszkowo-kręgosłupowego bez wodogtowia - opis przypadku}

\author{
Lidia Puchalska-Niedbał', Urszula Kulik', Klaudyna Kojder², Wojciech Lubiński, Beata Rzewuska², \\ Ireneusz Kojder ${ }^{2}$
}

${ }^{1}$ Katedra i Klinika Okulistyki Pomorskiego Uniwersytetu Medycznego w Szczecinie

al. Powstańców Wlkp. 72, 70-111 Szczecin

Kierownik: prof. dr hab. n. med. Wojciech Lubiński

${ }^{2}$ Katedra i Klinika Neurochirurgii Pomorskiego Uniwersytetu Medycznego w Szczecinie

ul. Unii Lubelskiej 1, 71-252 Szczecin

Kierownik: prof. dr hab. n. med. Ireneusz Kojder

\section{SUMMARY}

Introduction: We present a case of the patient suffering from the tumor of cranio-spinal junction in whom a wide spectrum of ophthalmic and neuroophtalmic signs was noted.

Methods: The comprehensive neuro-ophthalmic examination were performed (pupillary reactions, visual activity, fundus ophthalmoloscopy, intraocular pressures, eye movements, visual field, MRI, MR angiography). Additionally immunohistochemistry and laboratory tests were made.

Results: The case of 24 years male with peripapillary subretinal hemorrhage, that occurred after a surgical excision of a tumor at cranio-cervical junction. The mechanism of the dynamics of the expanding intracranial space occupying processes is also discussed.

Conclusions: Space occupying lesion of the level of cranio-spinal junction causes vascular changes in the fundus of the eye of the high dynamic and diversity. Surgical decompression in such cases is a maneuver of choice to maintain the reversibility of changes if proceeded in early stage.

Key words: peripapillary subretinal hemorrhage, increased intracranial pressure, acute diplopia, cranio-cervical junction tumors.

\section{STRESZCZENIE}

Wstęp: Opisano przypadek chorego cierpiącego z powodu guza okolicy połączenia czaszkowo-rdzeniowego bez wodogłowia u którego zaobserwowano neurologiczne nieprawidłowości i cechy oftalmologiczne wzmożonego ciśnienia wewnątrzczaszkowego. Metoda: Przeprowadzone zostały kompleksowo badania neurookulistyczne (z uwzględnieniem reakcji źrenic, ostrości wzroku, dna oka, ciśnienia śródgałkowego, ruchomości gałek ocznych, pola widzenia, MRI, MR z angiografią). Dodatkowo wykonano badania immunohistochemiczne i testy laboratoryjne.

Wyniki: U 24-letniego mężczyzny pojawiło się krwawienie podsiatkówkowe tuż przy tarczy nerwu wzrokowego po chirurgicznym wycięciu guza okolicy połączenia czaszkowo-kręgowego.

Wnioski: Przestrzeń dotknięta uszkodzeniem na granicy czaszkowo-rdzeniowej była przyczyną dynamicznych i rozmaitych zmian naczyniowych na dnie oka. Chirurgiczna dekompresja w tym przypadku była prawidłowym postępowaniem, które przyczyniło się do ustąpienia patologicznych zmian we wczesnym stadium ich rozwoju.

Słowa kluczowe: krwawienie podsiatkówkowe przytarczowe, podwyższone ciśnienie śródczaszkowe, guz połączenia czaszkowo-rdzeniowego.

\section{INTRODUCTION}

Peripapillary subretinal hemorrhage (PSH) is often associated with optic disc drusen $[1,2,3,4]$, optic discoedema $[5,6,7]$, peripapillary choroidal neovascular membrans $[8,9]$. Moreover, the spontaneous onset of an intrapapillary hemorrhage that extends in to the adjacent subretinal peripapillary region and occurs in patients who are Asian and myopic and have mildly dysplastic optic discplastic optic discs has been reported $[10,11,12]$. Hemorrhages are located in the medial-inferior parts in these individuals. Taking under consideration the role of orbital venous hypertension as well as that of cerebrospinal fluid (CSF) level opened to atmosphere during the surgery, hemorrhages seen on ophthalmologic examination might be relevant to acute intracranial pressure (ICP) rise. Which would be of forensic diagnostic value when compared to cases of head down hangmen or strangled ones. We present a case of a patient with tumor of cranio-spinal junction and its manifestation in optic disc and brain function to illustrate an extend the spectrum of symptoms and to draw attention to their possible mechanisms. 


\section{CASE REPORT}

A 24-year-old male was evaluated due to acute onset of diplopia and blurriness immediately after surgery due to cervical neuroma. Previously healthy individual, approximately 3 weeks prior to surgery experienced intense occipital headache, not responding to oral analgetics, gradually increasing and extending to became persistent by admission.

Upon the admission nuchal rigidity, tachycardia and high blood pressure were reported otherwise neurologically normal. Additional laboratory tests revealed elevated thyroid hormone titers (FT2,04 ng/dL). Apart from mild myopia (OD -0.75D) the remaining neuroophtalmic examination was normal (a.o. colour vision, pupils, motility and fundi). Propranol was administered, obtaining resolution of tachycardia and normalization of blood pressure. The preoperative MRI and MRI angiography excluded vascular malformations and showed the presence of tumor with intraparenchymal bleeding with no brain ventricles enlargement (Fig. 1).

Suboccipital craniotomy with laminectomies C1 and C2 in prone position was performed. Despite patient's positioning, CSF leaked under increased pressure at dural opening. A highly vascularized tumor with increased density, obstructing $1 / 3-1 / 2$ of upper spinal channel and almost completely closing foramen magnum was surgically excised by morcelation. Pathology examination revealed neurinoma (WHO grade 1).
By immunohistochemistry, tumor was positive for epithelial membrane antigen, S-100P, glial fibrillary acidic protein and vimentin. Apart from the persistence of deep sensory disturbances and slight muscle weakness in the right leg noticed after surgery, the patient's state rapidly improved. Due to acute onset of diplopia the patient was presented for ophthalmologic examination. Control RMN revealed absence of tumor and patency of CSF compartments in cranio-spinal region (Fig. 2).

9 days after surgery the patients did not complain any longer of diplopia, best corrected visual acuity was 20/20 in each eye. Color vison (tested by Ishihara plates) was normal, as there were the pupillary reactions. Intraocular pressures, eye movements and visual field (Goldman perimeter). Nevertheless, horizontal gaze nystagmus was noted. Dilated fundus examination revealed crescent shaped bilateral PSH with dilatation of the surface capillaries on the discs and congested veins. The optic nervehead appeared nondysplastic, without disc drusen, and pink. Ophtalmoscopy of the right eye showed blurring of the inferior disc margin and PSH located along the inferior region, spanning from 5 to 7 o'clock of the optic disc circumference and to third of the disc diameter in width. In the left eye PSH ranged from 5 to 7 and 1 to 11 o'clock, extended 2.0 from disc diameter. Blurred superior and inferior pole with focal inferior ischemic area were also noted. The fundus examination were otherwise normal. B-scan ultrasonography (USG-B; Eyecubed apparatus, $10.0 \mathrm{MHz}$ frequency probe) was performed

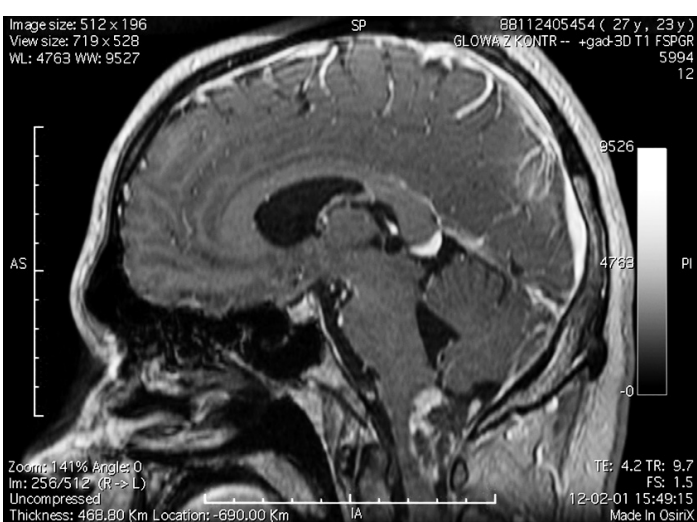

a

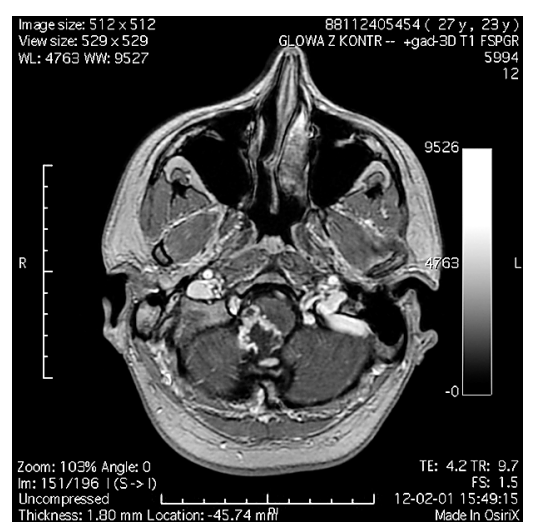

b

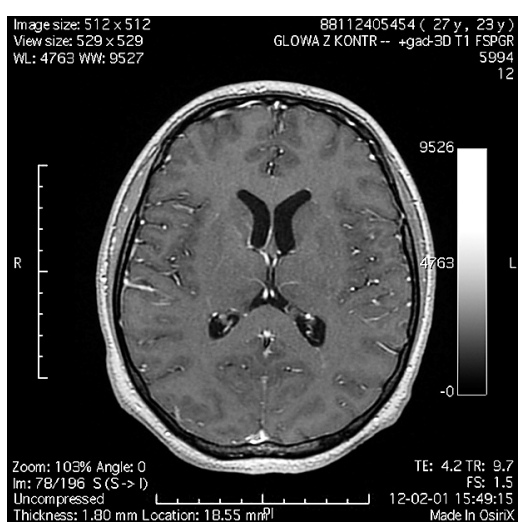

C

FIGURE 1. RMN revealing a mass at cranio-spinal junction $(a, b)$ with no ventricles dilatation (c)

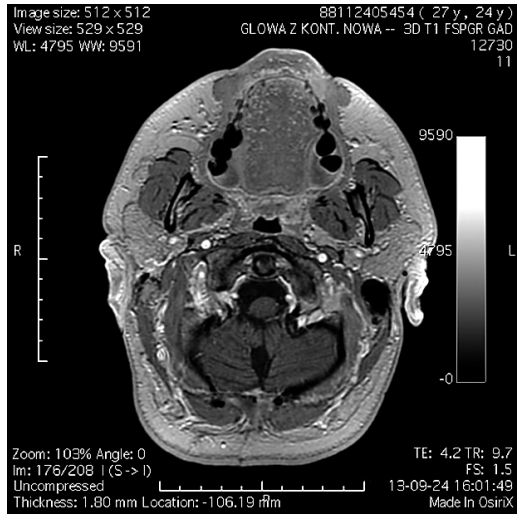

a

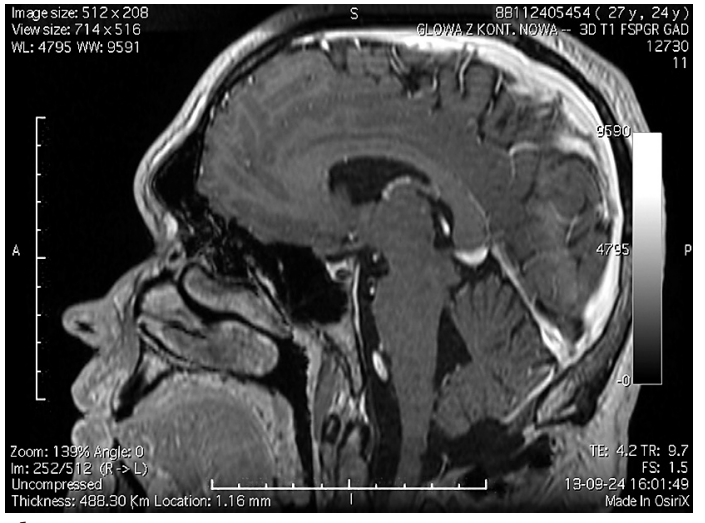

b

FIGURE 2. Postoperative view. No residual mass is seen 
specifically looking at the vitreopapillary relationships and the presence of optic nerve head druses using axial and longitudinal scans with high gain and scans perpendicular to the optic nerve. There was no evidence of partially detached posterior vitreous cortex inserting into the optic nerve or congenital abnormalities. At the follow up 2 months after initial examination hemorrhages and nystagmus spontaneously resolved without treatment.

\section{DISCUSSION}

Neurinoma diagnosed in our case is a benign, slow growing tumor of neurolemma (myelin sheath) of a nerve fiber. The proper diagnose can supported by substantially changed thickness of CNS structures around the tumor without accompanying neurological defects. This is due to mechanisms of pressure-volume compensation, particularly efficient at slowly enlarging tumors. Moreover, there were no features of intracranial hypertension in ophthalmoscopy in our patient before surgery. Intracranial pressure was however undoubtedly increased as demonstrated by the intraoperative assessment based on the dynamics of CSF outflow. In this respect, Usubiaga et al. [13] reports that as little as $10 \mathrm{~mL}$ of fluid infused in to the epidural space results in increased ICP, because any increase in epidural pressure is directly transmitted to the CSF, potentially causing the ICP rise. That occurs in use of even less volume $(2 \mathrm{~mL})$ as seen in our more recent observations [14]. Which is not so advanced in cases of compensatory brain structures sixth [15]. The latter was not encountered in our patients revealing not any lateral medial line brain displacement whatsoever taking on account symmetrical CDF outflow impairment at the level of foramen magnum. That is one of most important causes of ICP rise. And advanced space occupying lesion at cranio-vertebral junction cease essentially presso-volumetric compensation. This likely explains postoperative finding in the form of early papilloedema. It is striking to note that it took only as little as few hours of increased ICP with high dynamics to find that.

Optic disc oedema can be presented in various ways, depending on the evolution of the process, its severity and duration. The early stage is characterized by venous engorgement within the disc and the lack of spontaneous venous pulsations as seen in our patients. Both venous stasis and elevated level of central venous pressure, are considered to be the first signs of papilloedema. In addition, other early signs include disc hyperaemia, blurred disc margins presented in sequence from superiorly then inferiorly and nasally. In our case, PSH were found symmetrically in the upper and lower poles of the optic disc, wherein next to the left inferior pole occurred ischemic area. In such cases fundus image, should always be analysed with the visual acuity, and visual filed (enlarged blind spot) estimation. Visual acuity is not impaired initially but in later stages, the patient may complain of fleeting visual loss lasting seconds. In the case of prolonged, raised ICP visual acuity is reduced secondary to disc atrophy, and this may lead to complete and reversible amblyopia.
On the other hand, rapid nerve structure decompression and reduced ICP impact on both CSF and blood flow failure. In our patient, this resulted in local disorders causing postoperative medullar dysfunction manifested by muscle weakness and impaired deep sensation in the leg. The reduction of ICP that occurred during the operation can cause similar disorders in locations distant from the operated area, including the eye. However, there is no sufficient evidence which mechanism played a decisive role in this case, so both components should be considered: rised ICP and rapid decompression alike.

The inadvertent puncture of the dura mater occurring during epidural anesthesia, can cause leakage of CSF. Arcand et al. suggests that decrease of CSF pressure may lead to cranial nerve palsy through nerve traction [16], and the most commonly affected is the sixth nerve in its long, extracerebral course naked to CSF I tentorial incision. Moreover, Bell et al. [17] reports that, cranial nerve palsy is rare before the fourth day after the dura opening, and a period of remission of symptoms ranges from 2 weeks to 6 months. This findings are of value of explanatory sudden onset and latter disappearance of diplopia due to the cranial nerve palsy secondary to the elevated ICP in our case [18]. Sudden blindness when hypertensive ventricle or brain abscess is punctured and vigorously decompressed is observed in neurosurgical experience.

Rhythmic, spontaneous, symmetrical eye movement in the horizontal plane, especially pronounced when looking in the direction of the damaged cerebellar hemispheres were likely due to the compression of the pathways connecting the cerebellum with vestibular nuclei. After the cessation of increased ICP, functions of these structures were normalized.

\section{CONCLUSION}

In conclusion, the case is presented to highlight the fact that space occupying lesion of the level of cranio-spinal junction causes vascular changes in the fundus of the eye of the high dynamics and diversity. Which is noteworthy the latter occurs without causing hydrocephalus in this case. Surgical decompression in such patients is a maneuver of choice to maintain the reversibility of changes if proceeded in early stage. Which is specially important in era of radiotherapeutic methods recently being used toward the tumors of meningeal and neural pathology, that are of value in other localization than CSF pathways occlusion.

\section{REFERENCES}

1. Harris M.J., Fine S.L., Owens S.L.: Hemorrhagic complications of optic nerve drusen. Am J Ophthalmol. 1981, 92 (1), 70-76.

2. Hitchings R.A., Corbett J.J., Winkelman J., Schatz N.J.: Hemorrhages with optic nerve drusen. A differentiation from early papilledema. Arch Neurol. 1976, 33 (10), 675-677.

3. Sanders T.E., Gay A.J., Newman M.: Hemorrhagic complications of drusen of the optic disc. Am J Ophtalmol. 1971, 71, 204-217. 
4. Sanders T.E., Gay A.J., Newman M.: Drüsen of the optic disk-hemorrgahic complications. Trans Am Ophtalmol Soc. 1970, 68, 186-218.

5. Orcrutt J.C., Page N.G., Sanders M.D.: Factors affecting visual loss in benign intracranial hypertension. Ophtalmology. 1984, 91 (11), 1303-1312.

6. Castellarin A.A., Sugino I.K., Nasir M., Zarbin M.A.: Clinicopathological correlation of an excised choroidal neovascular membrane in pseudotumour cerebri. Br J Ophtalmol. 1997, 81 (11), 994-1000

7. Suzuki N., Takeda M., Takeda M., Hotta H.: Preretinal and retinal hemorrhage due to chronic subdural hematoma. Ann Ophthalmol. 1985, 17 (8), 494-497.

8. Browning D.J., Fraser C.M.: Ocular conditions associated with peripapillary subretinal neovascularization, their relative frequencies, and associated outcomes. Ophthalmology. 2005, 112 (6), 1054-1061.

9. Meredith T.A., Aaberg T.M.: Hemorrhagic peripapillary lesions in presumed ocular histoplasmosis. Am J Ophthalmol. 1977, 84 (2), 160-168.

10. Cibis G.W., Watzke R.C., Chua J.: Retinal hemorrhages in posterior vitreous detachment. Am J Ophthalmol. 1975, 80 (6), 1043-1046.

11. Kokame G.T., Yamamoto I., Kishi S., Tamura A., Drouilhet J.H.: Intrapapillary hemorrhage with adjacent peripapillary subretinal hemorrhage. Ophthalmology. 2004, 111 (5), 926-930.
12. Katz B., Hoyt W.F.: Intrapapillary and peripapillary hemorrhage in young patients with incomplete posterior vitreous detachment: signs of vitreopapillary traction. Ophthalmology. 1995, 102 (2), 354-394.

13. Usubiaga J.E., Usubiaga L.E., Brea I.M., Goyena R.: Effect of saline injections on epidural and subarachnoid space pressure and relations to postspinal anesthesia headache. Anesth Analg. 1967, 46 (3), 293-296.

14. Kojder I.: Intracranial pressio-volumetric compensation in spontaneous intracerebral hematoma. Neurol Neurochir Pol. 1992, 26, 497-501.

15. Kojder I., Benabid A.L., Herbowski L.: Relationship between shifts of brain medial line structures and intracranial pressure in rabbits. Neurosciences. 1993, 19, 1-4.

16. Arcand G., Girard F., McCormack M., Chouinard P., Boudreault D., Williams $S$.: Bilateral sixth cranial nerve palsy after unintentional dural puncture. Can J Anesth. 2004, 54 (8), 821-823.

17. Bell J.A., McIllwaine G.G., O'Neill D.: Iatrogenic lateral rectus palsies: a series of five postmyelographic cases. J Neuroophthalmol. 1994, 14 (4), 205-209.

18. Richards B.W., Jones F.R., Younge B.R.: Causes and prognosis in 4,278 cases of paralysis of the oculomotor, trochlear, and abducens cranial nerves. Am J Ophthalmol. 1992, 113 (5), 489-496. 